\title{
WPŁYW STABILIZACJI KRUSZYWA PODBUDOWY TRÓJOSIOWYM GEORUSZTEM NA NAWIERZCHNIĘ DROGOWĄ W POCZĄTKOWYM OKRESIE JEJ UŻYTKOWANIA
}

\author{
Marcin Grygierek ${ }^{凶}$ \\ Wydział Budownictwa, Politechnika Śląska, Gliwice
}

\begin{abstract}
STRESZCZENIE
Coraz częściej geosyntetyki stosuje się do poprawy cech mechanicznych warstwy podbudowy zasadniczej z niezwiązanego kruszywa. W tym przypadku geosyntetyk zlokalizowany w obszarze warstw o wysokiej sztywności musi charakteryzować się tzw. funkcją stabilizującą kruszywo w zakresie małych odkształceń. Funkcję tę spełniają georuszty o monolitycznych węzłach. W artykule przedstawiono wstępne wyniki programu badań opartego na obserwacji terenowego odcinka badawczego, który użytkowany jest przez pojazdy ciężkie. Dotychczasowe rezultaty pomiaru ugięć, równości oraz pomiaru odkształceń w warstwach nawierzchni za pomocą czujników odkształceń pozwalają zaobserwować korzystny wpływ georusztu na pracę niezwiązanego kruszywa. Na tym etapie badań przedstawione wnioski mają charakter jakościowy i wymagają weryfikacji na podstawie dalszych badań.
\end{abstract}

Słowa kluczowe: georuszt, badania terenowe, pomiar odkształceń, MES, FWD, nawierzchnia drogowa

\section{WSTĘP}

Obecnie geosyntetyki stanowia jedno z szeroko stosowanych materiałów w budownictwie. W zależności od zastosowanego polimeru oraz struktury budowy geosyntetyku przypisuje im się różne funkcje (Zornberg, 2017). W aspekcie poprawy nośności słabego podłoża istotne są te cechy geosyntetyku, które prowadzą do jego wzmocnienia. Według normy PN-EN ISO 10318:2007 charakter wzmacniający przypisuje się tzw. funkcji zbrojącej. Należy jednak zauważyć, że wymagania stawiane geosyntetykom o funkcji zbrojącej charakteryzują tylko jeden mechanizm pracy geosyntetyku określany tzw. efektem naciągniętej membrany. Bardzo ważnym parametrem charakteryzującym tę funkcję jest wytrzymałość geosyntetyku na rozciaganie, która określana jest dla okresu 120 lat. Istotą funkcji zbrojącej jest zapewnienie geosyntetykowi ciagłego stanu naprężeń rozciagających, aby „napięty” geosyntetyk odciążał podłoże znajdujące się poniżej geosyntetyku. Do tej grupy geosyntetyków zalicza się geosiatki oraz geotkaniny (rys. 1).

Jak wskazują wyniki badań (Giroud i Han, 2016a, b, c; Grygierek i Kawalec, 2017a), oprócz funkcji zbrojącej wyróżnia się również dwa inne mechanizmy pracy geosyntetyku, polegające na tzw. utwierdzeniu bocznym kruszywa oraz poprawie odporności warstwy na ścinanie (rys. 2).

Dwa kolejne mechanizmy pracy geosyntetyku związane są ze skrępowaniem ziaren kruszywa. Nieskrępowane ziarna kruszywa pod wpływem obciążenia starają się przemieścić, zwiększając pustki między

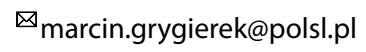


Grygierek, M. (2018). Wpływ stabilizacji kruszywa podbudowy trójosiowym georusztem na nawierzchnię drogową w początkowym okresie jej użytkowania. Acta Sci. Pol. Architectura, 17 (4), 39-49. doi: 10.22630/ASPA.2018.17.4.39

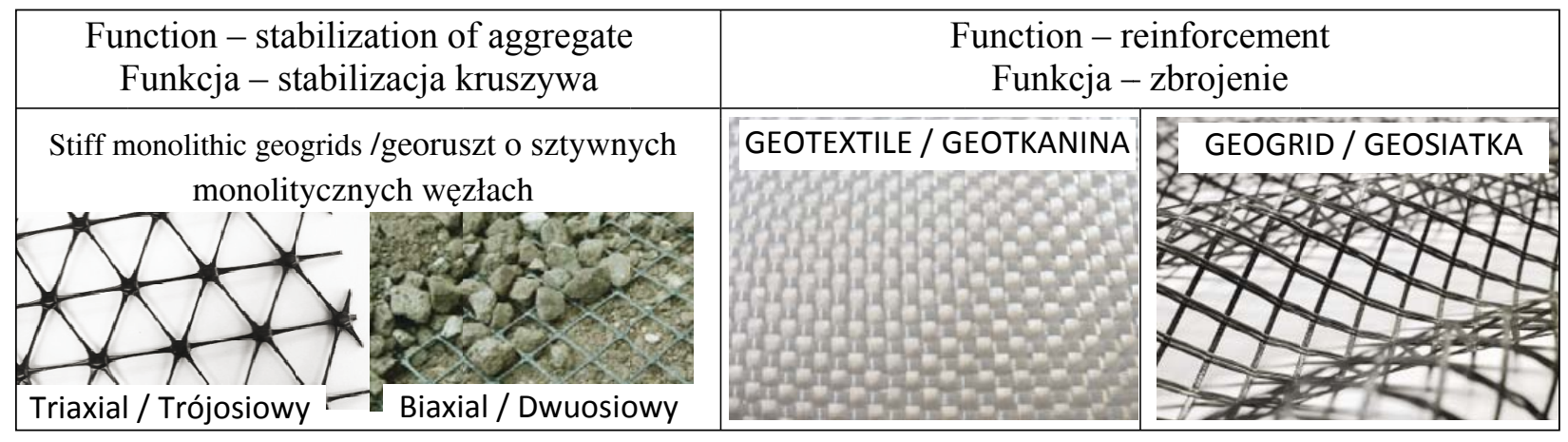

Rys. 1. Geosyntetyki o funkcji stabilizującej oraz zbrojącej niezwiązane kruszywo

Fig. 1. Geosynthetics materials stabilizing and reinforcing unbound aggregate

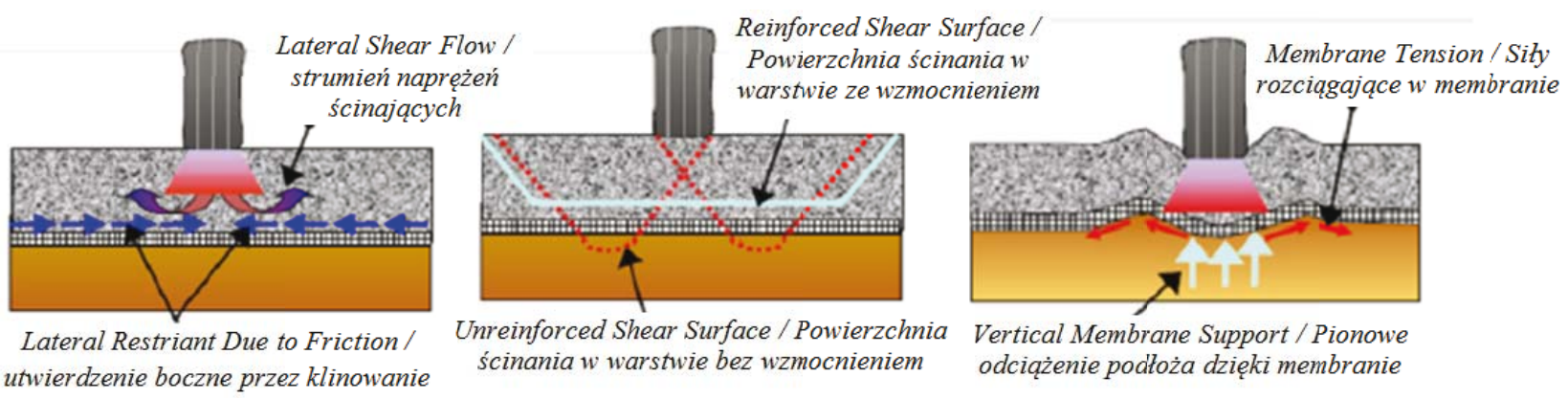

Rys. 2. Mechanizmy zachowania się geosyntetyku wzmacniającego warstwy (Zornberg i Gupta, 2010)

Fig. 2. Mechanisms of interaction between geosynthetic material and aggregate (Zornberg \& Gupta, 2010)

ziarnami i prowadząc $\mathrm{w}$ ten sposób do redukcji sztywności warstwy. Aby doszło do wzmocnienia warstwy kruszywa, geosyntetyk musi znacząco ograniczać przemieszczenia ziaren już w zakresie niewielkich odkształceń. W tych przypadkach za istotne właściwości geosyntetyku uważa się jego wysoką sztywność w zakresie tzw. małych odkształceń (Grygierek i Kawalec, 2017a). Sztywność ta determinowana jest budową połączenia przecinających się żeber/pasm tworzących strukturę geosyntetyku, ich grubością i sztywnością. Najlepsze właściwości w zakresie ww. mechanizmów przedstawiają georuszty o monolitycznych węzłach, wśród których wyróżnia się georuszty dwukierunkowe oraz trójosiowe (rys. 1). Georusztom, których konstrukcja węzłów i sztywność żeber umożliwia utwierdzenie boczne ziaren kruszywa, przypisuje się tzw. funkcję stabilizująca niezwiązane kruszywo (rys. 2). Mechanizm ten opisuje wiele prac badawczych (Zornberg i Gupta, 2010; Qian, Mishra, Tutumluerr i Kazmee, 2015; Giroud, 2016a, b, c; Rakowski, 2017; Zornberg, 2017).

Efektywność wzmocnienia podłoża geosyntetykiem jest tym większa, im słabsze jest podłoże. $Z$ tego też powodu wydaje się, że stosowanie geosyntetyków $\mathrm{w}$ górnych warstwach nawierzchni z niezwiązanego kruszywa, nie ma swojego technicznego uzasadnienia. Pogląd ten może być uzasadniany stosunkowo wysoką sztywnością warstw występujących w tym obszarze nawierzchni i niską efektywnością dodatkowego wzmocnienia warstwy kruszywa geosyntetykiem wbudowywanym na nośnym podłożu. Jak jednak wskazują wyniki badań (Oliver, Wayne i Kwon, 2016), stosowanie dodatkowego wzmocnienia warstwy podbudowy z niezwiązanego kruszywa poprawia parametry nawierzchni. Aczkolwiek efekt ten nie jest obserwowany w początkowym okresie użytkowania nawierzchni, tylko w dłuższym okresie użytkowania. W artykule przestawiono wybrane elementy programu badań oraz 
Grygierek, M. (2018). Wpływ stabilizacji kruszywa podbudowy trójosiowym georusztem na nawierzchnię drogową w początkowym okresie jej użytkowania. Acta Sci. Pol. Architectura, 17 (4), 39-49. doi: 10.22630/ASPA.2018.17.4.39

wyniki z początkowego etapu. W badaniach wykorzystano trójosiowy georuszt o monolitycznych węzłach do wzmacniania warstwy niezwiązanego kruszywa podbudowy zasadniczej.

\section{WPEYW GEORUSZTU NA PRACĘ WARSTWY KRUSZYWA}

Wpływ georusztu na stabilizowaną warstwę kruszywa $\mathrm{w}$ funkcji cykli obciążeniowych dobrze przedstawia rysunek 3 (Oliver i in., 2016). Obserwujemy na nim, że w zakresie do ok. 10000 cykli obciążeniowych brak jest istotnych różnic pomiędzy próbką kruszywa z georusztem lub bez niego. Dopiero powyżej 10000 cykli obciążeniowych obserwuje się różnice związane ze wzrostem odkształceń w próbce bez georusztu. Badanie $\mathrm{z}$ wykorzystaniem APLT (Automated Plate Load Test) (Wayne, Kwon i White, 2014; White i Vennapusa, 2017), pozwala w warunkach in situ zaobserwować wzrost modułu warstwy kruszywa stabilizowanego georusztem pod cyklicznym obciążeniem. Wzrost modułu obserwowany jest do ok. 10000 cykli obciążeniowych, później zachowanie warstwy kruszywa zbliżone jest do sprężystego. W badaniach z wykorzystaniem Heavy Vehicle Simulator (HVS) (Tingle i Jersey, 2010) także obserwuje się mniejszy przyrost koleiny w sekcji, w której zostało wbudowane kruszywo z georusztem.

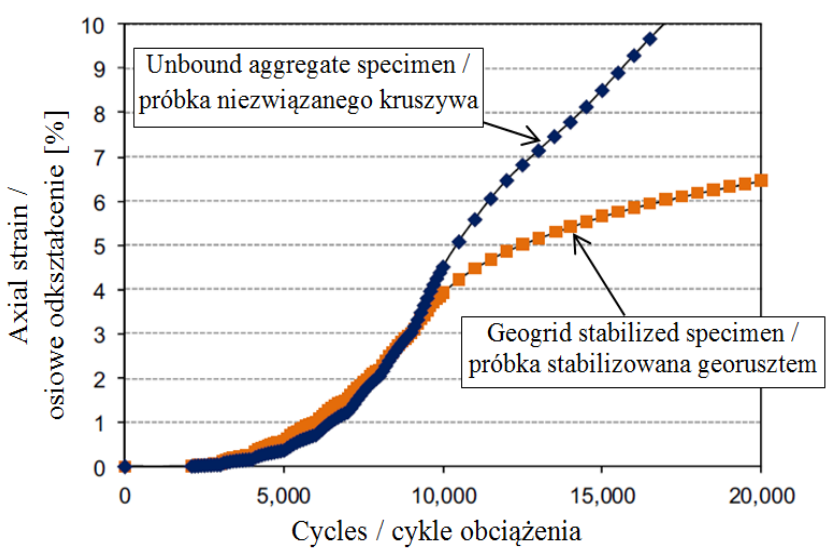

Rys. 3. Deformacja próbki kruszywa $\mathrm{z}$ trójosiowym georusztem i bez niego w cyklicznym obciążaniu (Oliver $\mathrm{i}$ in., 2016)

Fig. 3. Deformation of aggregate sample with/out triaxial geogrid under cyclical load (Oliver at al., 2016)

Efektywność skrępowania ziaren (stabilizacji) kruszywa w oczkach georusztu jest zmienna w funkcji odległości od płaszczyzny georusztu. Największa efektywność obserwowana jest na pewnej grubości w sąsiedztwie płaszczyzny georusztu (rys. 4), powyżej tej strefy wpływ georusztu na skrępowanie ziaren kruszywa maleje, a jeszcze wyżej zanika (Horvat, Fischer i Major, 2013; Horvat i Klompmaker, 2014; Han, 2016).

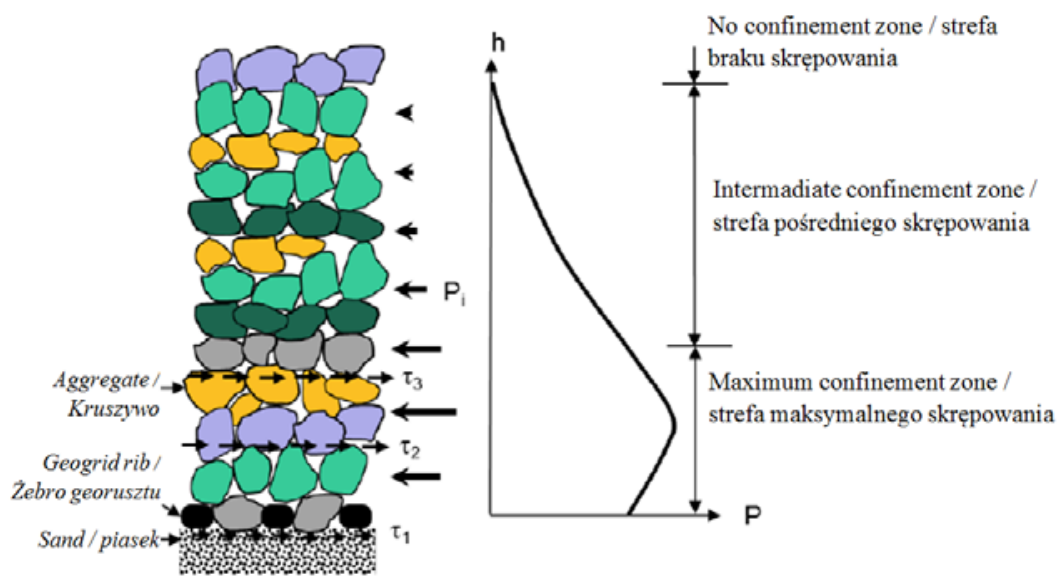

Rys. 4. Rozkład wpływu skrępowania ziaren kruszywa w matrycy georusztu w funkcji grubości warstwy (Horvat i in., 2013; Han, 2016)

Fig. 4. Distribution of influence of confinement of aggregate grains in geogrid matrix as function of layer thickness (Horvat at al., 2013; Han, 2016) 
Grygierek, M. (2018). Wpływ stabilizacji kruszywa podbudowy trójosiowym georusztem na nawierzchnię drogową w początkowym okresie jej użytkowania. Acta Sci. Pol. Architectura, 17 (4), 39-49. doi: 10.22630/ASPA.2018.17.4.39

Z przytoczonych rezultatów badań wynika, że stosowanie georusztu do stabilizacji niezwiązanego kruszywa może skutkować wymiernymi korzyściami w postaci wzrostu modułu sprężystości warstwy kruszywa i redukcji głębokości koleiny nawierzchni w porównaniu do nawierzchni, w której nie zastosowano georusztu. Z badań tych wynika również, że korzystny efekt stabilizacji kruszywa obserwowany jest po znaczącej liczbie cykli obciążeniowych. Należy zauważyć, że pomimo realizowanych badań konieczne jest prowadzenie dalszych w celu uszczegółowienia opisu zmiany parametrów warstwy kruszywa stabilizowanego georusztem, zwłaszcza na podstawie w badań w warunkach obciążania nawierzchni ruchem rzeczywistym.

\section{CHARAKTERYSTYKA ODCINKA BADAWCZEGO}

Badania terenowe realizowane są na użytkowanej drodze o długości 60 m (Grygierek i Kawalec, 2017b). Badany odcinek podzielony jest na trzy sekcje o długościach $20 \mathrm{~m}$. Układ i średnie grubości warstw nawierzchni w poszczególnych sekcjach przedstawia rysunek 5. Obserwowany odcinek stanowi dojazd do betoniarni i jest obciążany pojazdami dowożącymi materiały do produkcji betonu (pas wjazdowy) oraz pojazdami wywożącymi mieszankę betonową (pas wyjazdowy). W niniejszej pracy omawiane są wybrane wyniki badań tylko dla sekcji B i C, dla pasa wyjazdowego (rys. 5). Sekcje B i C różnią się między sobą występowaniem w sekcji B trójosiowego georusztu pod górną warstwą podbudowy z kruszywa. W wybranych warstwach nawierzchni zainstalowano czujniki, których celem jest pomiar poziomych odkształceń w warstwach niezwiązanego kruszywa, tj. w górnej warstwie z kruszywa dolomitowego 0/31,5 oraz dolnej warstwie $\mathrm{z}$ gruzu betonowego 0/63. Pomiar odkształceń dokonywany jest za pomocą czujników strunowych typu Geokon 4200 (Bednarski, Sieńko i Howiacki, 2015) zlokalizowanych w prawym śladzie koła na pasie wyjazdowym. Koncepcję ich rozmieszczenia w przekroju poprzecznym przedstawia rysunek 13. Oczekuję się, że w przypadku korzystnego wpływu zastosowanego georusztu zostaną zaobserwowane różnice w rozkładzie odkształceń pomiędzy sekcjami B i C. Pomierzone odkształcenia będą również wykorzystane do analiz numerycznych (rys. 13).

\section{Top view / Widok z góry}
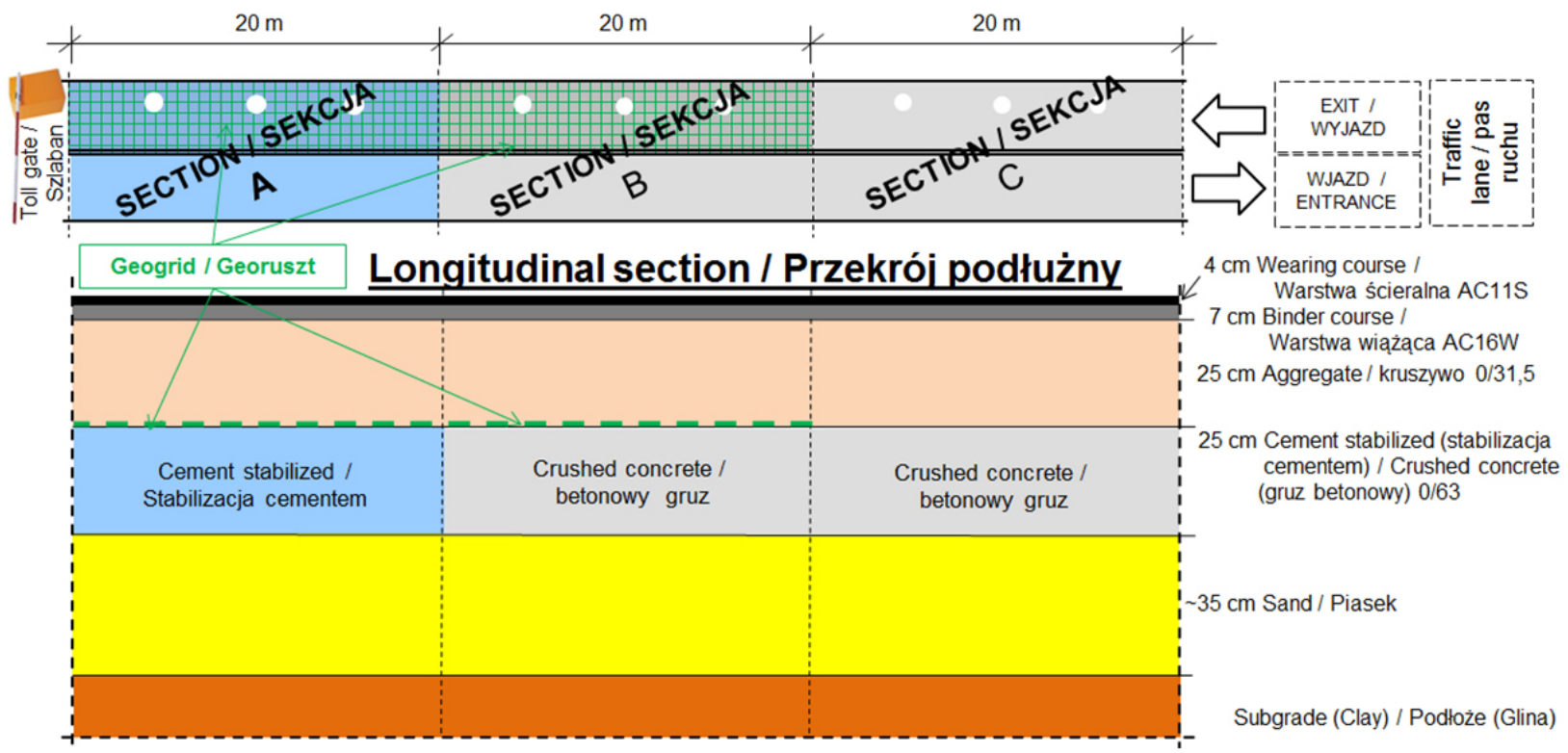

Rys. 5. Rozmieszczenie sekcji oraz lokalizacja trójosiowego georusztu w konstrukcji nawierzchni (Grygierek i Kawalec, 2017b)

Fig. 5. Distribution of sections and location of triaxial geogrid in pavement construction (Grygierek \& Kawalec, 2017b) 
Grygierek, M. (2018). Wpływ stabilizacji kruszywa podbudowy trójosiowym georusztem na nawierzchnię drogową w początkowym okresie jej użytkowania. Acta Sci. Pol. Architectura, 17 (4), 39-49. doi: 10.22630/ASPA.2018.17.4.39

\section{REALIZACJA I WYNIKI BADAŃ}

W artykule przedstawiono wyniki badań wykonanych w październiku 2016 roku oraz w listopadzie 2017. Podczas badań temperatura warstw mineralno-asfaltowych wynosiła odpowiednio $9^{\circ} \mathrm{C}$ i $5^{\circ} \mathrm{C}$. Na podstawie wstępnych obliczeń nawierzchnia do października 2016 przeniosła $\sim 850$ osi standardowych $100 \mathrm{kN}$, pomiędzy październikiem 2016 roku a listopadem 2017 $\sim 2600$ osi standardowych $100 \mathrm{kN}$, co sumarycznie daje $\sim 3450$ osi standardowych $100 \mathrm{kN}$.

Zakres badań terenowych obejmował pomiar ugięć nawierzchni ugięciomierzem FWD, pomiar równości poprzecznej, tj. głębokości kolein za pomocą klina i dwumetrowej laty. Prezentowane wyniki pomiaru ugięć nawierzchni zostały wykonane w prawym śladzie wyjazdowego pasa ruchu (linia A - rys. 6). Dodatkowo $\mathrm{w}$ trakcie sesji pomiarowej $\mathrm{w}$ listopadzie 2017 roku dokonano odczytu odkształceń z czujników zainstalowanych w warstwach kruszywowych pod statycznym obciążeniem powierzchni nawierzchni pojazdem ciężarowym (rys. 13). Niestety podczas pomiaru odkształceń poziomych wystapił problem z odczytem sygnału z czujnika z sekcji $\mathrm{C}$ zlokalizowanego w dolnej warstwie kruszywa, dlatego brak tej wartości na rysunku 13.

Wyniki ugięć nawierzchni, standaryzowanych tylko ze względu na wartość siły testowej, przedstawia rysunek 6. Rozkład ugięć wskazuje istotne różnice w sztywności nawierzchni pomiędzy sekcją B i C. Należy zauważyć, że nawierzchnia sekcji B, w której występuje georuszt, wykazuje większe ugięcia od nawierzchni z sekcji C, w której nie zastosowano georusztu.

Głębokość koleiny dla prawego śladu koła została przedstawiona na rysunku 7. Z analizy głębokości koleiny wynika, że w ostatnim okresie pomiędzy październikiem 2016 roku a listopadem 2017 nastąpił niewielki przyrost głębokości koleiny na sekcji $\mathrm{C}$, przy czym wzrost ok. $1 \mathrm{~mm}$ należy określić jako nieznaczny.

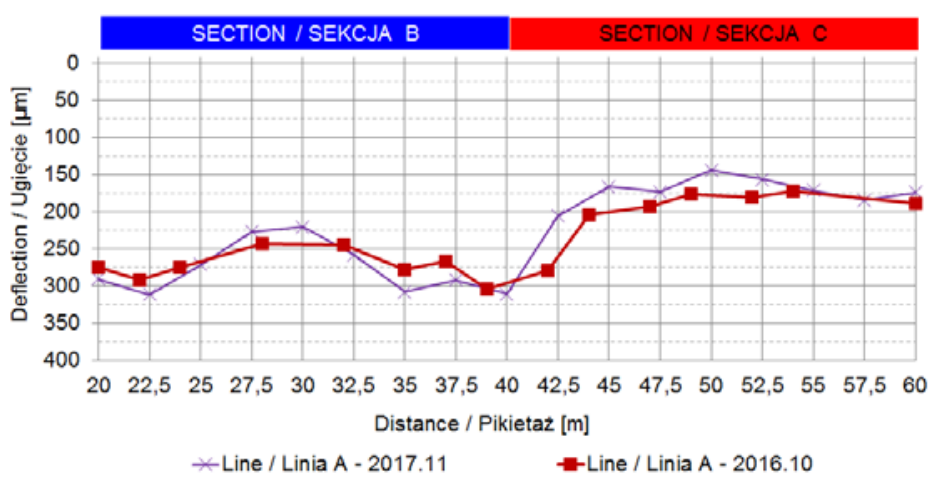

Rys. 6. Rozkład ugięć nawierzchni wzdłuż linii A - pomiar z października 2016 i listopada 2017

Fig. 6. Distribution of deflection in pavement along line A - measurement of October 2016 and November 2017

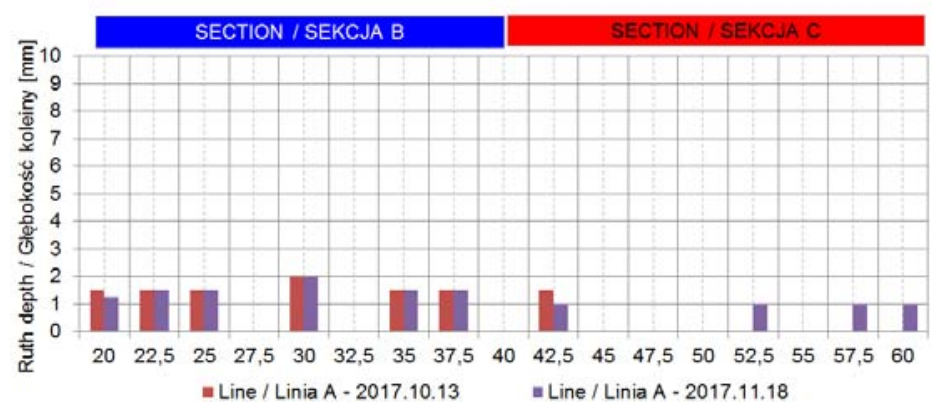

Rys. 7. Rozkład głębokości koleiny w prawym śladzie koła - pomiar z października 2016 oraz z listopada 2017

Fig. 7. Distribution of right wheel rut depth - measurements of October 2016 and November 2017 
Grygierek, M. (2018). Wpływ stabilizacji kruszywa podbudowy trójosiowym georusztem na nawierzchnię drogową w początkowym okresie jej użytkowania. Acta Sci. Pol. Architectura, 17 (4), 39-49. doi: 10.22630/ASPA.2018.17.4.39

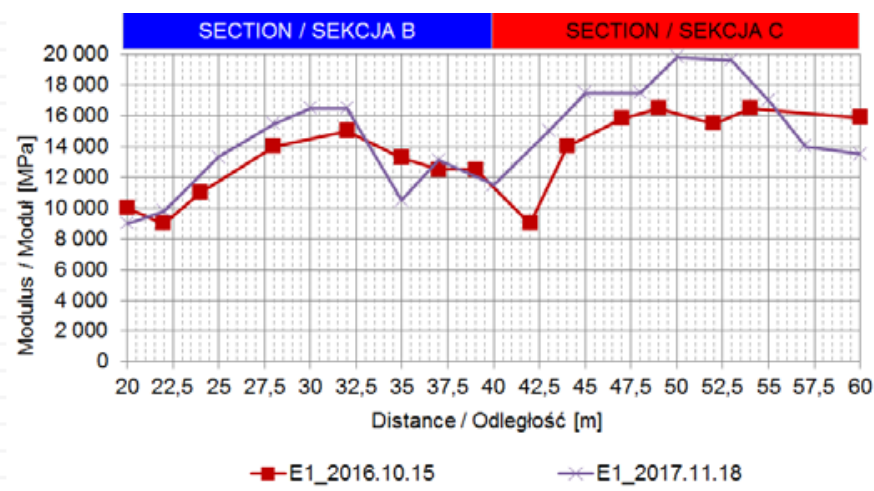

Rys. 8. Obliczone moduły dla warstw asfaltowych w temperaturze jak podczas pomiaru

Fig. 8. Calculated modules for asphalt layers, temperature as during measurement

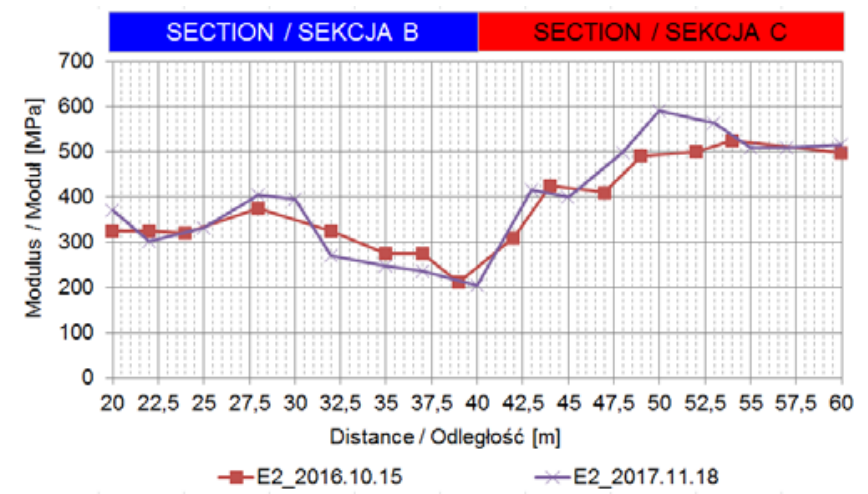

Rys. 9. Obliczone moduły dla pakietu warstw z kruszywa

Fig. 9. Calculated modules for a package of aggregate layers

\section{IDENTYFIKACJA MODUŁÓW WARSTW NAWIERZCHNI}

Na podstawie wyników pomiaru ugięć nawierzchni ugięciomierzem dynamicznym FWD obliczono moduły trójwarstwowego modelu nawierzchni. Przyjęto model o następujących średnich grubościach warstw: $12 \mathrm{~cm}$ pakiet mineralno-asfaltowy, $50 \mathrm{~cm}$ pakiet warstw z kruszywa dolomitowego oraz gruzu betonowego, podłoże gruntowe reprezentowane przez półprzestrzeń sprężystą.

Homogenizacja obu warstw kruszywowych i georusztu (dotyczy tylko sekcji B) powoduje, że obliczone moduły będą wartością ,uśredniona”, uwzględniająca łączny wpływ georusztu na górne kruszywo oraz zachowanie się dolnej warstwy $\mathrm{z}$ gruzu betonowego na sztywność pakietu kruszywa. Moduły warstw modelu nawierzchni poszukiwano metodą iteracyjną, dążąc do minimalizacji błędu dopasowania teoretycznej czaszy ugięć do czaszy ugięć według pomiaru terenowego. Zasady zastosowanej metodyki obliczania modułów przedstawia praca Szydło (1995). Ta sama metodyka była również wykorzystana przez Grygierka (2010). Do obliczeń wykorzystano program Bisar 3.0.

Obliczone wartości modułów (rys. 8-10) wskazują na niższą nośność podłoża w sekcji B (rys. 10) niż w sekcji C. Przyczyny tak znaczących różnic w wartościach modułów należy dopatrywać się m.in. w zróżnicowanej wilgotności warstw ulepszonego i rodzimego podłoża. Na sekcji B warstwa piasku była zabudowana po opadach deszczu, które spowodowały wzrost wilgotności samego piasku i występującej poniżej spoistego gruntu rodzimego. Podłoże nawierzchni na sekcji C było wykonywane w znacząco niższej wilgotności. 
Grygierek, M. (2018). Wpływ stabilizacji kruszywa podbudowy trójosiowym georusztem na nawierzchnię drogową w początkowym okresie jej użytkowania. Acta Sci. Pol. Architectura, 17 (4), 39-49. doi: 10.22630/ASPA.2018.17.4.39

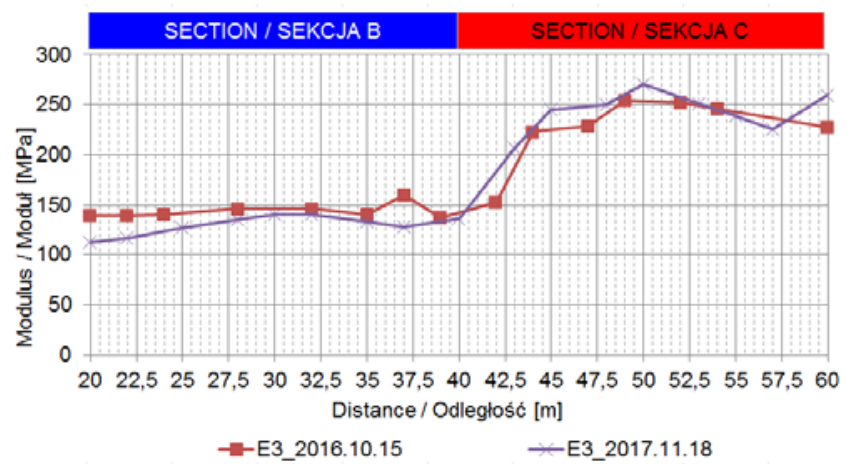

Rys. 10. Obliczone moduły dla podłoża nawierzchni

Fig. 10. Calculated modules for the soil

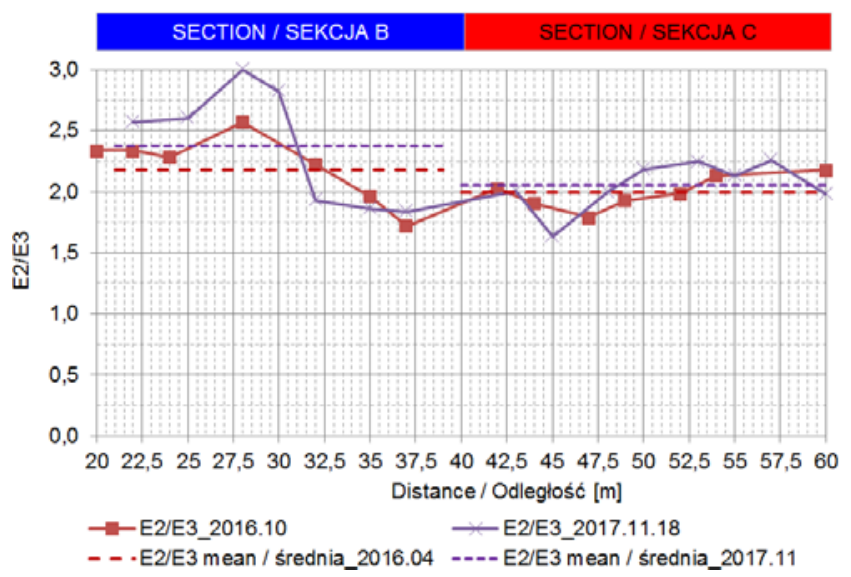

Rys. 11. Porównanie stosunku wartości modułu pakietu warstw z kruszywa (E2) do wartości modułu podłoża (E3)

Fig. 11. Comparison of ratio of values of package of aggregate layers (E2) to values of soil module (E3)

W związku z niższą sztywnością podłoża w sekcji B obserwuje się również niższe wartości modułów dla warstwy kruszywa niż w przypadku sekcji C (rys. 9). Należy jednak zwrócić uwagę na rozkład stosunku modułu pakietu warstw kruszywowych (E2) do modułu podłoża (E3) - E2/E3 (rys. 11). Z analizy rozkładu E2/E3 wynika, że została zbudowana wyższa sztywność pakietu warstw kruszywowych w sekcji B niż w sekcji C, oczywiście w odniesieniu do warunków panujących w podłożu nawierzchni. Wartość średnia E2/E3 w sekcji B wynosi 2,38 wobec wartości 2,05 w sekcji C. Zatem można stwierdzić, że wyższy stosunek E2/E3 w sekcji B związany jest z zastosowaniem georusztu w pakiecie warstw kruszywowych. Naturalnie wniosek ten wymaga potwierdzenia na drodze dalszych badań i analiz. Wartości modułów dla warstw asfaltowych w obu sekcjach są zróżnicowane, przyjmując nieco niższe wartości w sekcji B (rys. 8). Zgodnie $\mathrm{z}$ doświadczeniami (rys. 3) oczekuje się dalszego wzrostu sztywności warstw $z$ kruszywa stabilizowanych georusztem.

\section{PORÓWNANIE POMIERZONYCH I OBLICZONYCH POZIOMYCH ODKSZTAŁCEŃ W WARSTWACH KRUSZYWOWYCH}

Wartości pomierzonych odkształceń przez czujniki pod statycznym obciążeniem nawierzchni wskazuja na nieco niższe wartości poziomych odkształceń rozciągających w górnej warstwie kruszywa nawierzchni w sekcji B $(22 \mu \varepsilon)$ niż w sekcji C $(32 \mu \varepsilon)$ (rys. 13). Spostrzeżenie te, również łączy się $\mathrm{z}$ wpływem georusztu na wbudowane na nim kruszywo i efektem skrępowania ziaren, czyli ograniczania odkształcalności 
Grygierek, M. (2018). Wpływ stabilizacji kruszywa podbudowy trójosiowym georusztem na nawierzchnię drogową w początkowym okresie jej użytkowania. Acta Sci. Pol. Architectura, 17 (4), 39-49. doi: 10.22630/ASPA.2018.17.4.39

ośrodka ziarnistego (rys. 4). Obserwowane stosunkowo niskie odkształcenie w warstwie „nad” georusztem (sekcja B) w porównaniu do sekcji C jest tym bardziej znaczące, że w sekcji B podłoże charakteryzuje się znacząco niższą sztywnością niż podłoże w sekcji C.

Poziome odkształcenia w warstwach z kruszywa przeanalizowano również metodą elementów skończonych (MES) z wykorzystaniem programu Z Soil 11.03. Celem obliczeń była ocena zgodności pomierzonych poziomych odkształceń (czujniki odkształceń) $\mathrm{z}$ teoretycznym rozkładem (obliczonym) odkształceń obliczonych w modelu nawierzchni. Obliczenia MES wykonano, przyjmując uproszczenia m.in. polegające na homogenizacji warstw kruszywowych, w tym również pakietu warstw kruszywa ,przedzielonych” georusztem - sekcja B. Do obliczeń przyjęto obciążenie modelu zgodne z rzeczywistym (rys. 12). Na tym etapie obliczeń przyjęto model opisujący sprężyste zachowanie się wszystkich warstw nawierzchni. W modelu uwzględniono wpływ krawędzi nawierzchni na rozkład odkształceń poprzez zamodelowanie pobocza (rys. 12). Do obliczeń przyjęto zidentyfikowane moduły warstw nawierzchni (rys. 8-10) na podstawie pomiaru FWD (tab.).

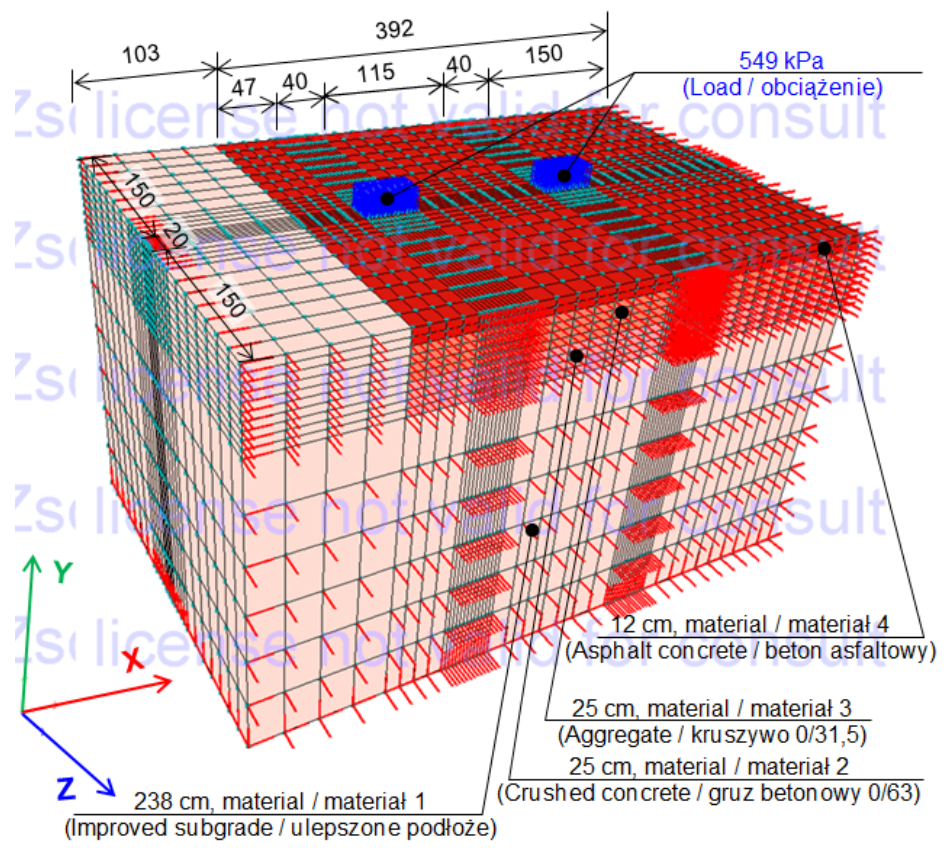

Rys. 12. Charakterystyka modelu nawierzchni - sekcja B i C. Wymiary podane $\mathrm{w} \mathrm{cm}$

Fig. 12. Characteristics of pavement model - section B and C. Dimensions in $\mathrm{cm}$

Tabela. Parametry modelu MES

Table. Parameters of FEM model

\begin{tabular}{lcccccc}
\hline \multirow{2}{*}{ Warstwa - layer } & \multicolumn{2}{c}{ Sekcja - Section B $(27,5 \mathrm{~m})$} & \multicolumn{3}{c}{ Sekcja - Section C (45 m) } \\
\cline { 2 - 8 } & $\begin{array}{c}E \\
{[\mathrm{MPa}]}\end{array}$ & $\begin{array}{c}v \\
{[-]}\end{array}$ & $\begin{array}{c}\gamma \\
{\left[\mathrm{kN} \cdot \mathrm{m}^{-3}\right]}\end{array}$ & $\begin{array}{c}E \\
{[\mathrm{MPa}]}\end{array}$ & $\begin{array}{c}v \\
{[-]}\end{array}$ & $\begin{array}{c}\gamma \\
{\left[\mathrm{kN} \cdot \mathrm{m}^{-3}\right]}\end{array}$ \\
\hline Beton asfaltowy - Asphalt concrete $12 \mathrm{~cm}$ & 15500 & 0,3 & 21 & 17500 & 0,3 & 21 \\
\hline Kruszywo (dolomit) - Agreggate (dolomite) $0 / 31,525 \mathrm{~cm}$ & 405 & 0,3 & 21 & 400 & 0,3 & 21 \\
\hline $\begin{array}{l}\text { Kruszywo (gruz betonowy) - } \\
\text { Agreggate (crushed concrete) } 0 / 6325 \mathrm{~cm}\end{array}$ & 405 & 0,3 & 21 & 400 & 0,3 & 21 \\
\hline \begin{tabular}{l} 
Podłoże - Subgrade \\
\hline
\end{tabular} & 135 & 0,3 & 21 & 245 & 0,3 & 21 \\
\hline
\end{tabular}


Grygierek, M. (2018). Wpływ stabilizacji kruszywa podbudowy trójosiowym georusztem na nawierzchnię drogową w początkowym okresie jej użytkowania. Acta Sci. Pol. Architectura, 17 (4), 39-49. doi: 10.22630/ASPA.2018.17.4.39
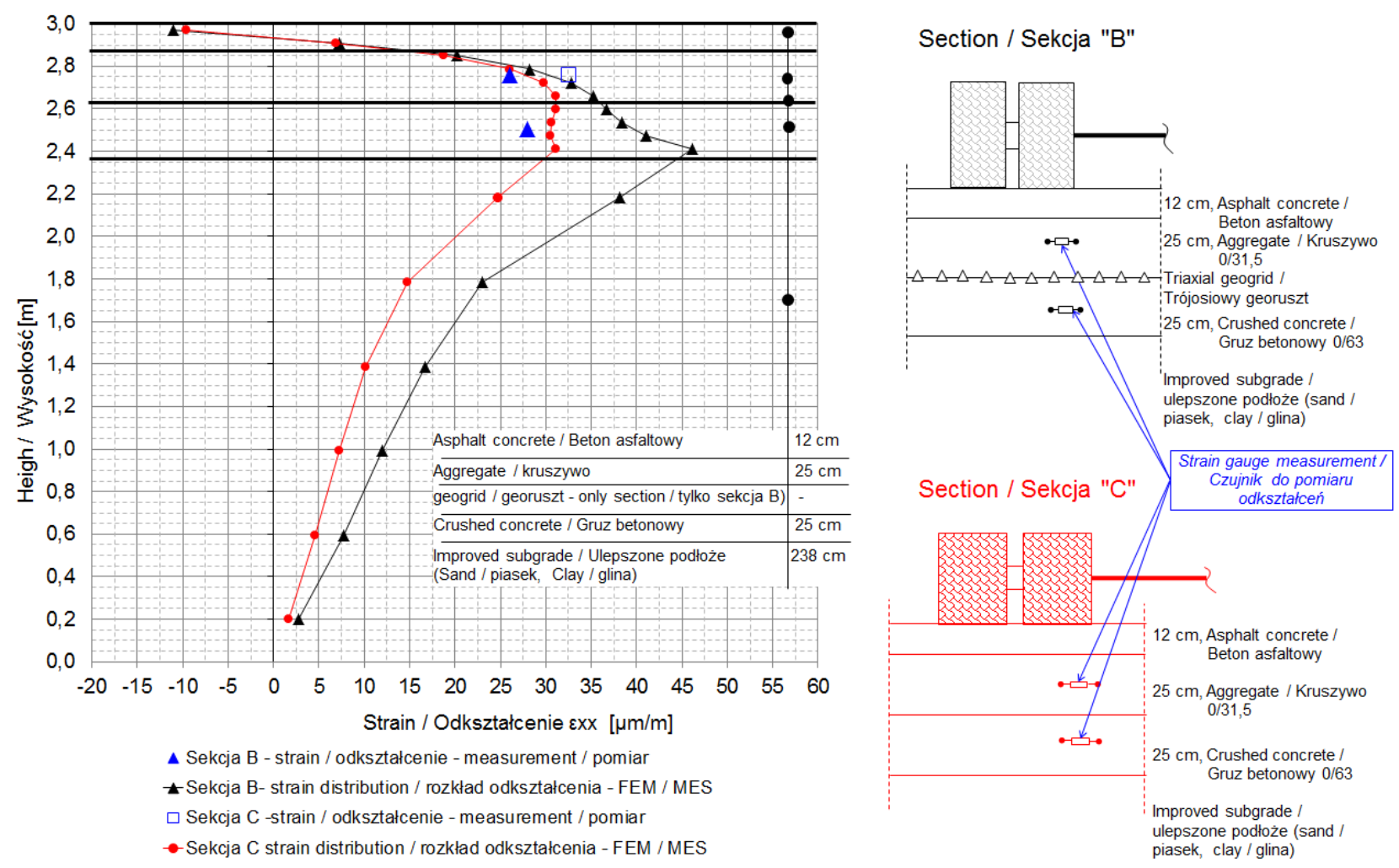

Rys. 13. Porównanie pomierzonych odkształceń $w$ terenie $z$ wartościami obliczeniowymi

Fig. 13. Comparison of deflections measured in situ with calculated values

Prezentując porównania poziomych odkształceń w nawierzchni, w sekcji B i C (rys. 13), należy zauważyć poprawną zgodność $\mathrm{w}$ wartościach odkształceń pomierzonych i obliczonych w modelu. Bardziej szczegółowa analiza odkształceń będzie przedmiotem dalszych prac.

\section{WNIOSKI}

W pracy przedstawiono wyniki badań $i$ analiz dotyczących obserwacji z początkowego okresu użytkowania nawierzchni, w której zasadnicza warstwa kruszywa jest stabilizowana trójosiowym georusztem o monolitycznych węzłach (sekcja B).

$\mathrm{Na}$ podstawie zidentyfikowanych modułów warstw nawierzchni stwierdza się, że w sekcji B występują niższe moduły pakietu warstw niezwiązanych niż w sekcji C, co jest konsekwencją niższej nośności podłoża w sekcji B niż w sekcji C. Korzystny wpływ zastosowania georusztu w pakiecie warstw kruszywowych w sekcji B obserwuje się, analizując stosunek modułu E2 (moduł pakietu kryszywowego) do E3 (moduł podłoża). W sekcji B stosunek E2/E3 wynosi 2,38, w sekcji C stosunek E2/E3 wynosi 2,05. Z tego porównania wynika, że w pakiecie warstw kruszywowych zawierającym georuszt można uzyskać wyższą wartość modułu w funkcji modułu podłoża niż wówczas, gdy nie zastosuje się georusztu.

Analiza rozkładu pomierzonych odkształceń poziomych w warstwie kruszywa nad poziomem wbudowania georusztu wskazuje, że zastosowanie georusztu redukuje wartość poziomych odkształceń, co istotnie poprawie „posadowienie” pod warstwami mineralno-asfaltowymi. Jednak wniosek ten ma charakter jakościowy i wymaga potwierdzenia na podstawie dalszych badań.

$\mathrm{Na}$ podstawie pomierzonej głębokości koleiny stwierdza się niewielki przyrost koleiny w kilku punk- 
Grygierek, M. (2018). Wpływ stabilizacji kruszywa podbudowy trójosiowym georusztem na nawierzchnię drogową w początkowym okresie jej użytkowania. Acta Sci. Pol. Architectura, 17 (4), 39-49. doi: 10.22630/ASPA.2018.17.4.39

tach w sekcji C, wobec braku przyrostu kolein w sekcji B - zawierającej georuszt. Przyrost koleiny w sekcji C osiaga wartość $1 \mathrm{~mm}$.

Na podstawie badań i analizy wyników z początkowego okresu użytkowania testowego odcinka drogi można zauważyć korzystny wpływ trójosiowego georusztu na pracę podbudowy zasadniczej, a tym samym całej nawierzchni. Jednak dotychczasowe wnioski maja charakter jakościowy i konieczne jest prowadzenie dalszych badań, zwłaszcza w kontekście wzrastającej liczby cykli obciążeniowych i oczekiwanych dalszych zmian parametrów nawierzchni (równość, nośność) na obu sekcjach B i C.

\section{PIŚMIENNICTWO}

Bednarski, Ł., Sieńko, R. i Howiacki, T. (2015). Wybrane zagadnienia monitorowania konstrukcji. XXX Jubileuszowe Ogólnopolskie Warsztaty Pracy Projektanta Konstrukcji, Szczyrk.

Giroud, J. i Han, J. (2016a). Mechanisms governing the performance of unpaved roads incorporating geosynthetics. Geosynthetics, 34 (1), 22-36.

Giroud, J. i Han, J. (2016b). Field evaluation of the performance of unpaved roads incorporating geosynthetics - Planning. Geosynthetics, 34 (2), 26-41.

Giroud, J. i Han, J. (2016c). Field evaluation of the performance of unpaved roads incorporating geosynthetics - Implementation, Geosynthetics, 34 (3), 26-36.

Grygierek, M. (2010). Variability of elastic moduli of unbound layers of road pavements subjected to ravelling strains due to mining. Roads And Bridges - Drogi i Mosty, 9 (2), 17-30.

Grygierek, M. i Kawalec, J. (2017a). Selected Laboratory Research on Geogrid Impact on Stabilization of Unbound Aggregate Layer. Procedia Engineering, 189, 484-491.

Grygierek, M. i Kawalec, J. (2017b). Evaluation of pavement with Geogrid stabilized unbound aggregate base within initial phase of trafficking. GeoAfrcica, Marrakech, Morocco, Conference proceedings, vol. 2, 864-871.

Han, J. (2016). Recent advances in geosynthetic stabilization of roads: Terminologies, products, and mechanisms. The 6th Regional Conference on Geosynthetics, New Delhi, India.
Horvat, F. i Klompmaker, J. (2014). Investigation of confinement effect by using the multi-level shear box test. Proceedings of the 10th International Conference on Geosynthetics, Berlin, Germany.

Horvat, F., Fischer, S. i Major, Z. (2013). Evaluation of railway track geometry stabilisation effect of geogrid layers under ballast on the basis of laboratory multi-level shear box tests. Acta Technica Jaurinensis, 6 (2), 21-44.

Oliver, T., Wayne, M. i Kwon, J. (2016). Mechanical Stabilization of Unbound Layers to Increase Pavement Peformance and Incorporation of Benefits into M-E analysis. Procedia Engineering, 143, 896-910.

PN-EN ISO 10318:2007. Geosyntetyki - Terminy i definicje.

Qian, Y., Mishra, D., Tutumluer, E. i Kazmee, H. A. (2015). Characterization of geogrid reinforced ballast behavior at different levels of degradation through triaxial shear strength test and discrete element modeling. Geotextiles and Geomembranes, 43 (5), 393-402.

Rakowski, Z. (2017). An attempt of the synthesis of recent knowledge about mechanisms involved in stabilisation function of geogrids in infrastructure constructions. Procedia Engineering, 189, 166-173.

Szydło, A. (1995). Statyczna identyfikacja parametrów modeli nawierzchni lotniskowych. Wrocław: Oficyna Wydawnicza Politechniki Wrocławskiej.

Tingle, J. S., Jersey, S. R. (2010). Full-scale accelerated pavement tests geogrid reinforcement of thin asphalt pavements. Phase 1 Interim report. US Army Corps of Engineers. Engineer Research and Development Center.

Wayne, M. H., Kwon, J. \& White, D. J. (2014). Assessment of pavement foundation stiffness using cyclic plate load test. Conference Proceeding $10^{\text {th }}$ International Conference on Geosynthetics, ICG 2014, Berlin.

White, D. J. i Vennapusa, P. K. R. (2017). In situ resilient modulus for geogrid-stabilized aggregate layer: A case study using automated plate load testing. Transportation Geotechnics, 11, 120-132.

Zornberg, J. G. (2017). Functions and applications of geosynthetics in roadways. Procedia Engineering, 189, 298-306.

Zornberg, J. G. i Gupta, R. (2010). Geosynthetics in pavements: North American contributions. In Theme Speaker Lecture. Proceedings of the 9th International Conference on Geosynthetics, Guarujá, vol. 1, Brazil, 379-400. 
Grygierek, M. (2018). Wpływ stabilizacji kruszywa podbudowy trójosiowym georusztem na nawierzchnię drogową w początkowym okresie jej użytkowania. Acta Sci. Pol. Architectura, 17 (4), 39-49. doi: 10.22630/ASPA.2018.17.4.39

\title{
INFLUENCE OF AGGREGATE BASE STABILIZED WITH TRIAXIAL GEOGRID ON PAVEMENT AT THE INITIAL STAGE OF ITS USE
}

\begin{abstract}
Geosynthetic materials are more and more often applied to improve mechanical properties of a loose aggregate base layer. In such a case, geosynthetic material located within layers of high rigidity must be able to stabilize small deformations of aggregate. Geogrids of monolithic joints play such a role. The article presents initial results of a research program based on observations of a field test section, which is used by heavy vehicles. Hitherto results of measuring deflection, evenness and deformations in pavement layers with sensors, show that the geogrid has a beneficial influence of on the performance of loose aggregate. The conclusions presented at the stage of research are qualitative ones and require verification with further research.
\end{abstract}

Key words: geogrid, in situ test, measurement of strain, Finite Elements Method, Falling Weight Deflectometer, pavement 